\title{
French report seeks to slow fusion project
}

Paris. A decision to build the International Thermonuclear Experimental Reactor (ITER), intended to demonstrate the feasibility of nuclear fusion as a source of energy, should not be taken until all the technological problems facing the project have been resolved experimentally, according to an advisory panel to the French government.

In a report published in Paris last week, it also says the decision should not happen until ITER's long-term financing is guaranteed. At the same it warns that heavy expenditure by France on a European space programme that includes a commitment to the international space station could have a damaging impact on other areas of research.

"There is a sentiment that we need to go more slowly on ITER," says Georges Laurens, secretary of the Conseil des Grands Equipements Scientifiques, which advises the government on large scientific projects.

In its report, the panel argues that the decision due to be taken in 1998 on whether to build ITER needs to be considered within a broader review of the goals of fusion research. Even if ITER gets the go-ahead, it should not be allowed to crush other promising avenues of fusion research, such as basic plasma physics, says the report.

The report also calls for scientists unconnected with ITER to be given a greater say in the running of the project. Laurens says that the need for more external input was "strongly emphasized" by the panel.

The panel's recommendations tie in closely with a growing consensus in both the

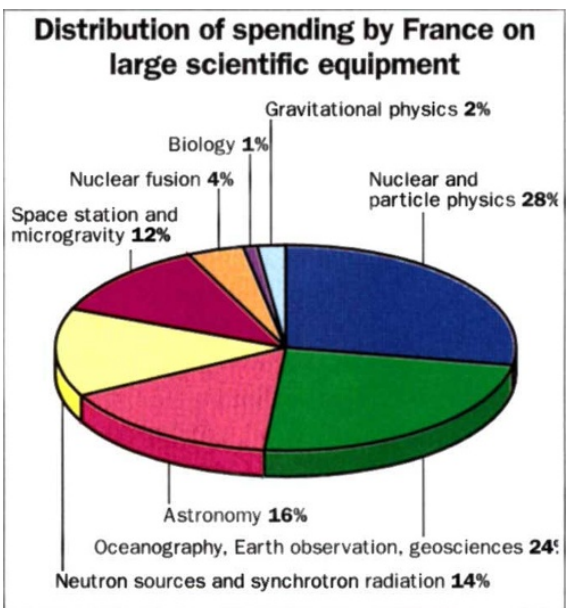

United States and the European Union (see Nature 377, 567; 1995 \& 380, 655; 1996) that the ITER project needs to be reassessed, given its estimated $\$ 10$ billion costs.

But although Laurens supports a review of ITER, he also claims much of the opposition to ITER is an "unscientific" knee-jerk response, and warns against what he describes as a growing trend among researchers themselves to attack large-scale science projects on the grounds that the money could be better spent elsewhere.

$\mathrm{He}$ points out that funding for such projects is usually extra money provided on top of existing research budgets, and that when planned facilities such as the US Superconducting Super Collider are cancelled, the money saved is usually reallocated to areas other than research.

Indeed, the report argues that 'megascience' projects are now the driving force in many areas of research. But Laurens warns that the huge costs of such projects are making international collaboration and hardheaded decision-making vital. (France will spend FF2.4 billion (US\$460 million), excluding staff costs, on large science projects this year, around 10 per cent of state spending on research.)

For example, despite loud demands from European researchers for new neutron sources (see Nature 379, 284; 1996), the panel recommends against a spending spree on new facilities, arguing that much of the anticipated needs for neutrons could be met relatively cheaply by upgrading existing sources. Similarly, Laurens says that France should "watch" plans for a European Spallation Source, but "not push" for the facility.

While French and British researchers are keen to build independent synchrotron radiation sources (see Nature 381, 100; 1996), the panel swims against the current, describing one machine built by several countries as a "very desirable" alternative.

But in financial terms the report's biggest concern is the impact that the space station will have on France's budget for large-scale scientific projects. Its share of this budget is scheduled to grow from 7 per cent last year to 16 per cent in 1999. If this increase is paid for by making reductions in other astronomy programmes, the effect could be disastrous, says Laurens.

Declan Butler

\section{Freshwater research struggles to keep head above water}

Ottawa. Canada's federal government has denied claims that funding cuts are likely to lead to the demise of a freshwater research programme described as the "crown jewel" of Canadian environmental science.

Despite rumours to the contrary, L. Scott Parsons, assistant deputy minister for science in Fisheries and Oceans Canada says that the government has no intention of closing either the Freshwater Institute, its Experimental Lakes Area (ELA) programme, or the Canada Centre for Inland Waters at Burlington, Ontario.

Parsons acknowledges that the ELA programme faces a 55 per cent cut in its operating budget and the loss of 21 of its 49 scientific staff over the next five years. But, he says, this forms part of a broader picture of cuts to science programmes.

The overall budget of the fisheries and oceans department is being cut by some 40 per cent, and the science portion of that, amounting to $\mathrm{C} \$ 199$ million (US\$146 million), is being reduced by C $\$ 71$ million.

The budget cuts have also affected other research activities in the fisheries and oceans department. For example, a 60 per cent reduction has been made in the Atlantic salmon enhancement programme in Canada's maritime provinces, a centre of parasitology in Quebec has been closed, and the department's major oceanographic vessel was mothballed.

The ELA is a collection of 48 small lakes near the Ontario-Manitoba border. The institute has gained worldwide scientific acclaim for its use of the lakes as living laboratories, collecting data over 25 years and studying the effects of pollutants.

The cuts have been strongly criticized from both within and outside the institute. Eville Gorham, Regents' professor of ecology at the University of Minnesota, described the reductions as "a catastrophe". Digby McLaren, a former president of the Royal Society of Canada, said they are "an absolute disgrace".

The reductions led to the resignation last year of Bob Hecky, the scientist in charge of the institute's freshwater science programme. Hecky said that he did not want to preside over what he considered to be the dismantling of the institute. He added that parallel cuts at the Burlington station would destroy much of Canada's research on the Great Lakes, which hold more than onefifth of the world's fresh water.

Indeed, Hecky says he believes that the cuts will effectively destroy the institute's entire research programme unless other funding sources are found. He says that although there has been a federal commitment to maintaining the ELA's monitoring programmes, the government has let it be known it will not undertake any new work. But Parsons disagrees and says there was a "moderation" of the cuts last December.

In recent decades, the institute has published pioneering studies of the effects of phosphates and acid rain on aquatic life, and of extremely long-distance airborne transfer of pesticides. A report of ELA work published recently in Nature (380, 694 ; 1996) showed how methylmercury is broken down by light action on surface waters, overturning previous ideas of how mercury makes its way through the environment.

David Spurgeon 